\title{
Review
}

\section{James Parkinson: The Man Behind the Shaking Palsy}

\author{
Patrick A. Lewis* \\ Department of Molecular Neuroscience, UCL Institute of Neurology, London, UK
}

\begin{abstract}
James Parkinson occupies a unique position in the history of Parkinson's disease. As the man responsible for originally identifying and describing the disease that he called the Shaking Palsy, his name is familiar to anybody with a connection with the disease - patients, carers, clinicians and members of the general public alike. This review summarises the life and career of one of the most recognizable names in neurology.
\end{abstract}

Keywords: History of neurology, Parkinson's disease, James Parkinson

Although there is anecdotal evidence of Parkinson's disease throughout much of history [1-3], the establishment the disease as a clinically distinct movement disorder has its origins in the work of James Parkinson, a medical practitioner working in London around the turn of the 19th century. Much of what we know about Parkinson's life comes from the diligent research of Leonard George Rowntree, a lecturer at Johns Hopkins Medical School in Baltimore, who wrote a seminal report on the life of James Parkinson in 1912 [4]. James William Keys Parkinson was born on 11th April, 1755 in what was then the village of Hoxton in Middlesex, just to the north of the City of London (Fig. 1A) [5, 6]. Hoxton is now filled with fashionable bars and restaurants, benefiting from its proximity to the banks and financial establishments that crowd the City of London. Throughout the course of his life, James Parkinson will have witnessed huge changes in the lives of the people who lived and worked around Hoxton as it was slowly swallowed up by the rapidly expanding metropolis and underwent the upheavals of the industrial revolution. Much of his life was spent in and around Hoxton

${ }^{*}$ Correspondence to: Patrick A. Lewis, Department of Molecular Neuroscience, UCL Institute of Neurology, Queen Square, London WC1N 3BG, UK. Tel.: +44(0)20348841016; Fax: +44(0)20 7278 5069; E-mail: Patrick.lewis@ucl.ac.uk.
Square: although the house in which he grew up in and lived, number 1 Hoxton Square, has been demolished (the only existing photo is shown in Fig. 1B), a blue plaque commemorates his close association with the area (Fig. 1C) [4].

\section{EARLY LIFE AND MEDICAL CAREER}

We know very few details of his early life. His parents, John and Mary, had three children - James (the eldest), William and Mary [7]. John Parkinson worked as a doctor in and around Hoxton, being a member of the company of surgeons, and this obviously influenced the young James Parkinson. Following in his father's footsteps, he enrolled at the London Hospital in 1776. A fascinating insight into Parkinson's views on training to be a doctor is provided by a series of letters he compiled as a pamphlet on medical education in 1800 entitled "the hospital pupil". In it, he detailed the requirements and system of a medical education, emphasizing that "a sympathetic concern, and a tender interest for the sufferings of others, ought to characterize all those who engage themselves in a profession, the object of which should be to mitigate, or remove, one great portion of the calamities to which humanity is subject" [8]. It is likely that much of the 

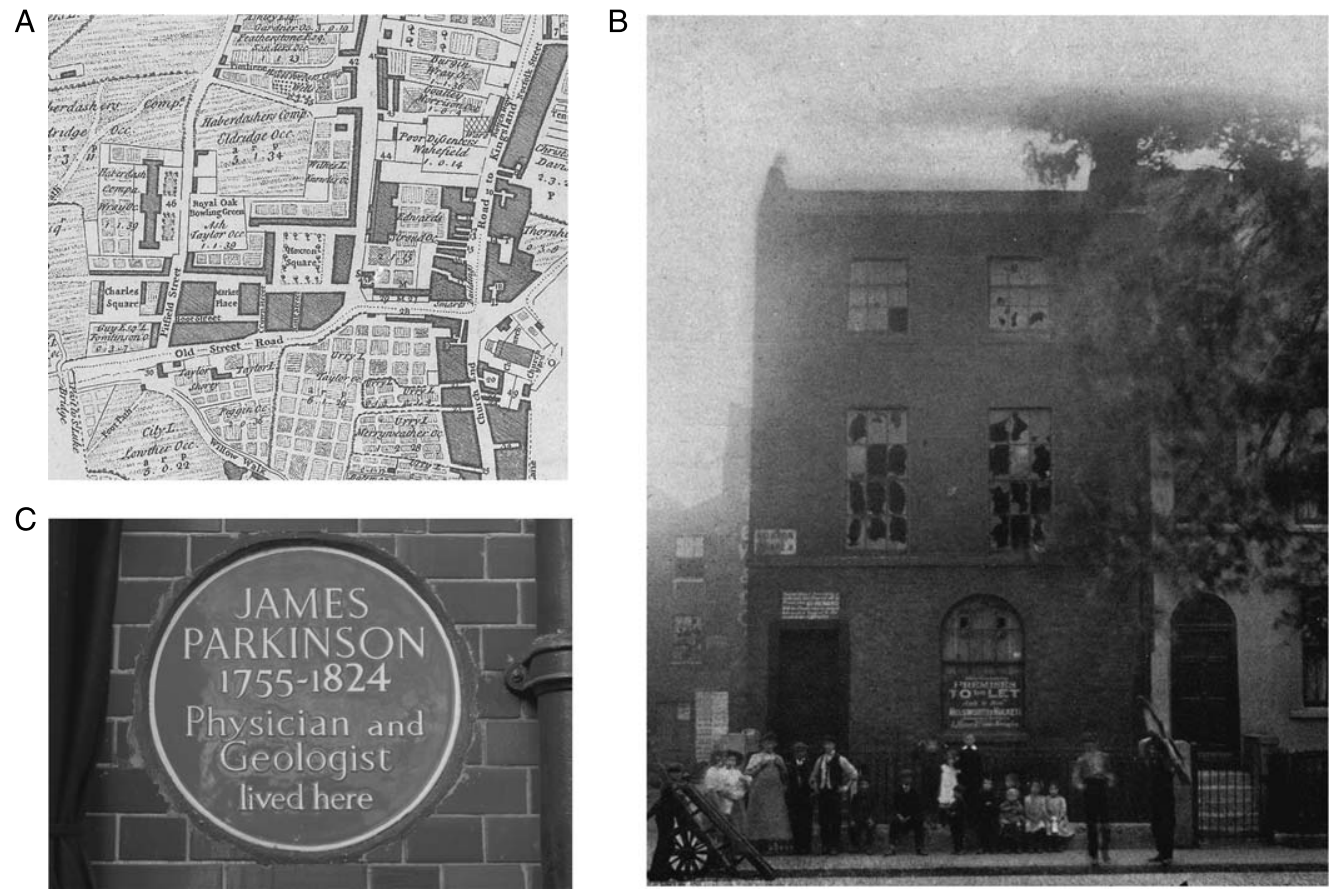

Fig. 1. James Parkinson's Hoxton. (A) A survey of Shoreditch from 1745, just prior to James Parkinson's birth, showing Hoxton square (centre) and St. Leonard's church (lower right corner) (C) British Library Board Cartographic Items 577.h.17 (B) Photo of 1, Hoxton Square dating from 1912 (taken from reference [4]) (C) The plaque commemorating James Parkinson on 1, Hoxton Square today.

advice dispensed in this book came from Parkinson's own experience of entering the medical profession. He was awarded a diploma of the Company of Surgeons (the precursor to the Royal College of Surgeons) in 1784 , just a few months after the death of his father. In the days before such a job description existed, James Parkinson operated as a general practitioner in Hoxton for several decades, later in partnership with his son (also called James), who took over the running of the practise from his father when he retired [7, 9]. In addition to attending to the general health and wellbeing of the people of Hoxton, Parkinson was also heavily involved in the welfare of patients in the numerous mental health institutions, the Hoxton madhouses, that were located in and around Hoxton [10].

Parkinson was an active member of the medical community in London, and was elected a Fellow of the Medical Society of London in 1787 . He wrote papers and pamphlets for the medical community and for consumption by the general public, presenting his first paper to the Medical Society of London in 1787 entitled "Some Account on the Effects of Lightning" [11]. For a more general readership, he wrote several books of medical advice, for example The Town and Country Friend and Physician. This dispensed advice on medical issues ranging from "bleeding from the nose" to the "folly of too much care and anxiety after health" [12]. An example of the esteem in which James Parkinson's peers held him is his involvement with the Association of Apothecaries - an organisation that played an important role in the passing of the Apothecaries act of 1815, which in turn was an important step towards the development of a comprehensive medical education for medical practitioners [13]. Parkinson was heavily involved in the association, and was elected president in 1817 serving two terms [14].

\section{THE SHAKING PALSY}

Parkinson's extensive clinical experience and observational skills, gleaned from several decades of medical practice in Hoxton, served him well in what was to be his outstanding contribution to medical science - his description of the Shaking Palsy (Fig. 2) [15, 16]. From the outset it is clear that he was well aware of how devastating the disease could be:

"the unhappy sufferer has considered it as an evil, from the domination of which he had no prospect of escape" 

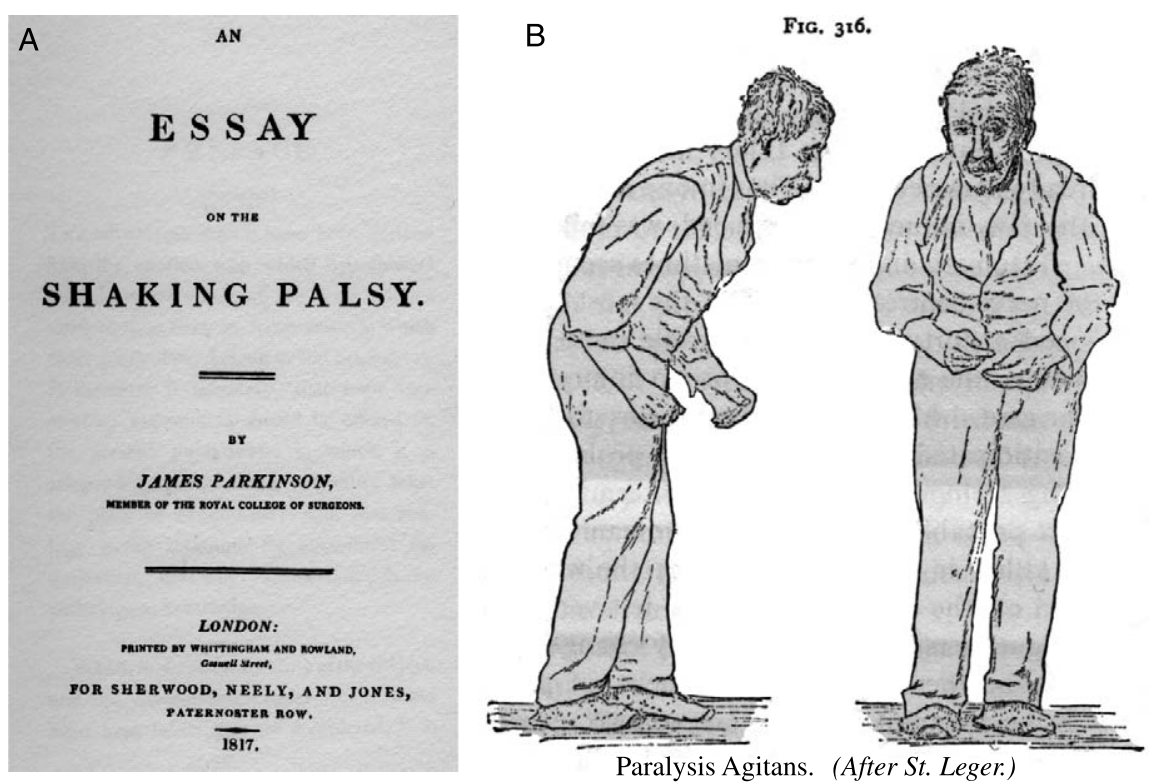

Fig. 2. James Parkinson's legacy to the field of neurology (A) The frontispiece to his essay on the Shaking Palsy, written in 1817. (B) An illustration of an individual with Parkinson's disease from William Gower's work Manual of the Diseases of the Nervous System written in 1886.

It is remarkable, and a testament to Parkinson's powers of observation, how much of the essay on the Shaking Palsy remains relevant to the description of patients with Parkinson's disease today [17, 18]. His definition of the Shaking Palsy is worth reproducing in full. He described it as a disease characterised by an:

"Involuntary tremulous motion, with lessened muscular power, in parts not in action and even when supported; with a propensity to bend the trunk forwards, and to pass from a walking to a running pace: the senses and intellects being uninjured."

The major difference between Parkinson's definition and the modern understanding of Parkinson's disease is with regard to his final observation, the importance of non-motor symptoms, as there is an increasing realisation that dementia is an important part of the symptomatic spectrum of Parkinsonism [19].

The centrepiece of the essay is Parkinson's report of a typical history for the Shaking Palsy, illustrated with a series of six cases from in and around Hoxton, sharing a number of characteristic symptoms. Although varying in detail (only two of the cases were directly examined by Parkinson, and of these a detailed case history was taken in one case), these contain a wealth of information that neurologists today would recognise from their own interaction with Parkinson's disease patients [18].
Much is made in the essay of the inadequacy of the treatments available to sufferers. The optimism of Parkinson's humanist tendencies prompted him to suggest that: "there appears to be sufficient reason for hoping that some remedial process may ere long be discovered, by which, at least, the progress of the disease may be stopped". Sadly it was to be 140 years before the work of Arvid Carlsson and others eventually led to the development of levodopa as a symptomatic treatment for the Shaking Palsy, and we still await an intervention that actually retards the progress of the disease.

It is important to note, when reading an essay on the Shaking Palsy, that Parkinson was working in uncharted territory. The study of neurological disease as we know it today was very much in its infancy, and the degenerative diseases that are so familiar now, such as Motor Neuron Disease or Alzheimer's Dementia, were still many years from being established as clinical entities. As the medical discipline of neurology took shape over the course of the 19th century, a number of its founding fathers (most notably Jean-Martin Charcot in Paris and Williams Gowers in London) acknowledged the contribution that Parkinson had made in bringing together and synthesising the case reports that he published in his essay on the Shaking Palsy [20-23]. The most obvious consequence of this was the naming of the disease in recognition of Parkinson's influence on the field. 


\section{PARKINSON'S LIFE OUTSIDE OF MEDICINE}

Although it is his clinical work that has made its mark on history, during his lifetime Parkinson was as well known for his radical political views and his contribution to the emerging field of geology. As a young doctor, he wrote passionately and profusely on the subject of social reform. It should be remembered that Parkinson lived through turbulent times: the American declaration of independence was signed in 1776, and the French revolution started in 1789. Across Europe and the new world, the old order was being challenged, and Britain was no exception. In particular, there were growing calls for more representative government and an extension of the right to vote - calls which eventually led to the reform act of 1832. James Parkinson was an active voice in these calls, being a member of two of the leading London societies campaigning for reform of the electoral system: the London Corresponding Society and the Society for Constitutional Information [5]. Membership of such societies was controversial, and there were numerous attempts by the authorities to suppress publications by these societies and indeed to quash the societies full stop. Parkinson contributed to these debates under the pseudonym Old Hubert [24], writing a number of satirical, and for the time somewhat seditious, pamphlets directed at the establishment (Fig. 3) [25, 26].

It was through the London Corresponding Society that he became embroiled in the scandal surrounding an alleged attempt to assassinate King George III, immortalised as the Pop Gun Plot [27]. A number of members of the society were accused of high treason and imprisoned pending trial. Parkinson was called in

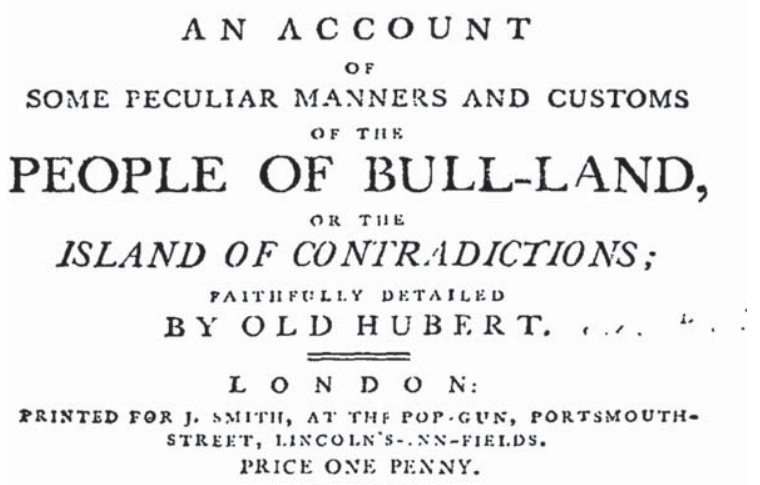

Fig. 3. Frontispiece from a pamphlet written by James Parkinson under the pseudonym Old Hubert. front of the Privy Council (a group of government ministers and lords acting as advisors to the king or queen of Great Britain) to face questioning regarding these individuals. In fact, we have a first hand account of this interrogation from Parkinson himself based upon his own shorthand notes (he was a strong proponent of shorthand, and encouraged medical students to take up the practice of this approach) and published in a contemporary pamphlet [28]. He was questioned directly by William Pitt the Younger, the prime minister of the time:

Mr. Pitt. - Pray, Mr. Parkinson, how came you to be invited on this committee?

Mr. Parkinson. - Because I believe they did me the honour to believe me firm in the cause (Mr. Pitt smiled) of Parliamentary Reform, and because I had just published a little tract for the benefit of the wives and children of the persons imprisoned on charges of High Treason.

Although it caused something of a stir at the time, it soon transpired that the plot was essentially a fabrication, and charges were dropped. It would appear that, as his medical practice increased, Parkinson moved away from the cause of social reform to focus more closely on medical issues - as witnessed by the publications and studies referred to above - along with a number of observations on other scientific subjects.

An example of this is his Chemical Pocket Book [29], a layperson's guide to the world of chemistry. This proved very popular, and ran to several editions before being overtaken by the rapid advances in chemistry over the first few decades of the 19th century [30]. More fundamental are his observations in the field of geology, and in particular palaeontology. In 1807 he was one of thirteen founder members of the Geological Society [31], and published a number of seminal observations on sedimentary rocks and the fossil record (Fig. 4A) [32, 33]. In recognition of this, a species of Ammonite (a now extinct type of mollusc) was named after him in 1821 by the naturalist James Sowerby [34] (Fig. 4B), making James Parkinson remarkable in having both a fossil species and a disease named after him. A further honour was bestowed upon him by the Royal College of Surgeons, who awarded Parkinson their honorary gold medal in 1823 for his work on fossils, noting that: "The fruits of your exertions are distinguished by the stamp of simplicity and truth. They express the most laudable zeal in the pursuit and the promulgation of knowledge, for the benefit of mankind" [35]. 

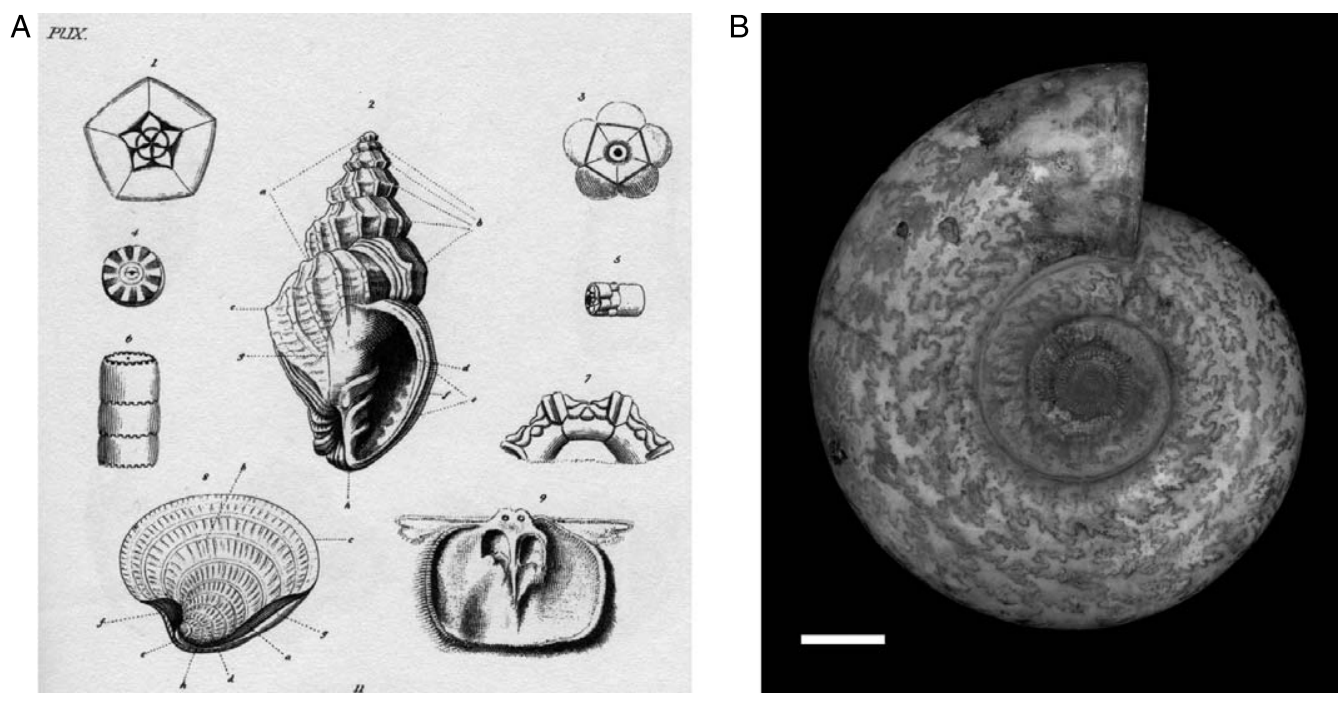

Fig. 4. James Parkinson's contribution to palaeontology. A) Illustration from his book on fossil remains Outline of Oryctology B) Parkinsonia dorsetentsis, an extinct ammonite from the family named in honour of James Parkinson (scale bar: $5 \mathrm{~cm}$. Image courtesy of the National History Museum, London).

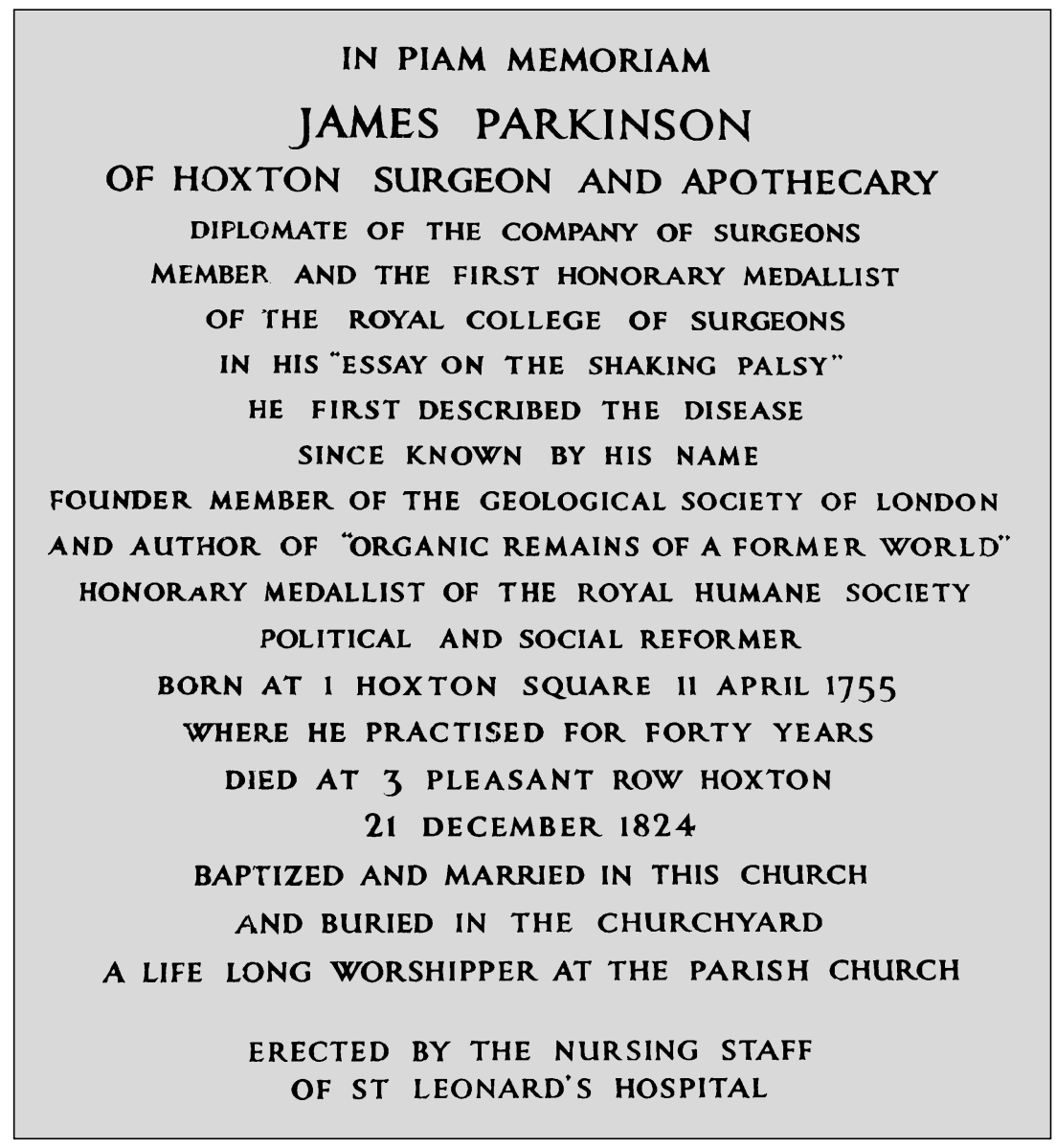

Fig. 5. The plaque in St. Leonard's church, Hoxton, commemorating James Parkinson. 


\section{CONCLUSION}

James Parkinson died on the 21st of December 1824 on Kingsland Road, only a few hundred yards from the house where he grew up. His passing was much lamented by the Parish of St. Leonard's, and was noted with regret in the Parish records, as well as in the Gentleman's Magazine [36]. For many years there was no monument to his achievements. However a plaque commemorating James Parkinson and his work was placed in the nave of St. Leonard's church in 1955 , the 200th anniversary of his birth (Fig. 5) [30]. Unfortunately, no image of James Parkinson has survived (although a photo has mistakenly been attributed to him on the internet [37]), but, through his prolific writings, we can generate a good idea as to nature of this man. What emerges is a portrait of someone who was very much a product of the enlightenment, and in many ways ahead of his time clinically, scientifically and politically.

What would James Parkinson think now about the Shaking Palsy? He would certainly marvel at the progress that has been made in terms of diagnosing and understanding the causes of the disease that now bears his name. It is likely that he would be pleased at the range of drugs now used to ease the symptoms that he described so clearly in his essay. But undoubtedly he would be both surprised and disappointed to discover that, almost two centuries after he had first noted the existence of the disease, there is still no cure for this devastating disorder.

\section{FURTHER READING}

There are many papers in the literature detailing the life and work of James Parkinson, a number of which are cited in the reference list below. For a more detailed account of James Parkinson's life, James Parkinson: his life and times by AD Morris is the most in depth biography available [7]. Several of Parkinson's papers are available on the internet, include a reprint of his Essay on the Shaking Palsy [16], and examples of his other political, medical and geological papers. For a general introduction to the history of Parkinson's disease, the article on this subject by Dr Christopher Goetz is highly recommended [1].

\section{ACKNOWLEDGMENTS}

P.A.L. is a Parkinson's UK research fellow (fellowship F1002). The author would like to thank the
Michael J. Fox Foundation and Parkinson's UK for funding support. This work was supported in part by the Wellcome Trust/MRC Joint Call in Neurodegeneration award (WT089698) to the UK Parkinson's Disease Consortium (UKPDC) whose members are from the UCL Institute of Neurology, the University of Sheffield and the MRC Protein Phosphorylation Unit at the University of Dundee. The author would like to acknowledge the Natural History Museum, London, for supplying the image of $P$. dorsetentsis: Deborah Pritchard, Warden of St Leonard's Church, Hoxton, London; Paul Espinosa of the Peabody Library, Johns Hopkins University for the image of 1 Hoxton Square. Reproduction of the 1745 survey of Shoreditch is by kind permission of the British Library board. The author thanks Dr R.K. Gordon, Dr P.R. Lewis and S. Hampton for helpful comments and discussion.

\section{REFERENCES}

[1] Goetz CG (2011) The history of Parkinson's disease: Early clinical descriptions and neurological therapies. Cold Spring Harbor Perspectives in Medicine, 1, a008862.

[2] Zhang ZX, Dong ZH, \& Roman GC (2006) Early descriptions of Parkinson disease in ancient China. Archives of Neurology, 63, 782-784.

[3] Manyam BV (1990) Paralysis agitans and levodopa in "Ayurveda": Ancient Indian medical treatise. Movement disorders: Official Journal of the Movement Disorder Society, $\mathbf{5}$, 47-48.

[4] Rowntree L (1912) James Parkinson. Bulletin of the Johns Hopkins Hospital, 23, 33-46.

[5] Morris AD (1955) James Parkinson, born April 11, 1755. Lancet, 268, 761-763.

[6] Chassereau P (1745) J. Nichols, London.

[7] Morris AD (1989) James Parkinson his Life and Times, Birkhauser, Boston.

[8] Parkinson J (1800) The Hospital Pupil, H.D.Symonds, London.

[9] Roberts S (1997) James Parkinson: From Apothecary to General Practitioner, Royal Society of Medicine, London.

[10] Morris AD (1958) The Hoxton Madhouses, Goodwin Bros., London.

[11] Parkinson J (1789) Some account of the effects of lightning. Memoirs of the Medical Society of London, 2, 493-503.

[12] Parkinson J (1803) The town and country friend and physician, J Humphreys, Philadelphia.

[13] (1815) in 55 Geo.1ll, c.194.

[14] (1823) Transactions of the associated apothecaries and surgeon apothecaries of England and Wales, I, clxxi.

[15] Parkinson J (1817) An essay on the shaking palsy, Sherwood, Neely and Jones, London.

[16] Parkinson J (2002) An essay on the shaking palsy 1817 J Neuropsychiatry Clin Neurosci, 14, 223-236; discussion 222.

[17] Lees AJ, Hardy J, \& Revesz T (2009) Parkinson's disease. Lancet, 373, 2055-2066.

[18] Kempster PA, Hurwitz B, \& Lees AJ (2007) A new look at James Parkinson's Essay on the Shaking Palsy. Neurology, 69, 482-485. 
[19] Caballol N, Marti MJ, \& Tolosa E (2007) Cognitive dysfunction and dementia in Parkinson disease. Movement Disorders : Official Journal of the Movement Disorder Society, 22(Supp1 17), S358-S366.

[20] Goetz CG (1986) Charcot on Parkinson's disease. Movement Disorders: Official Journal of the Movement Disorder Society, 1, 27-32.

[21] Gowers WR (1886) A manual of diseases of the nervous system, J \& A Churchill, London.

[22] Charcot J (1887) lecons du Mardi a la SaIpetriere 1887-1888 - lecons 9, 21, 22, Bureaux du prgres medical, Paris.

[23] Charcot J (1879) Lectures on the diseases of the nervous system, Henry Lea, Philadelphia.

[24] Tyler KL, \& Tyler HR (1986) The secret life of James Parkinson (1755-1824): The writings of Old Hubert. Neurology, 36 , 222-224.

[25] Parkinson J (1793) An address to the Hon. Edmund Burke from the Swinish Multitude, J. Ridgeway, London.

[26] Parkinson J (1795) An account of the people of Bull Land or the island of contradictions, J. Smith, London.

[27] Emsley C (2000) The pop gun plot In Radicalism and revolution in Britain 1775-1848, Davis M, ed, Macmillan, London.
[28] Smith J (1795) Assassination of the king!, London

[29] Parkinson J (1800) The Chemical Pocket Book, London.

[30] Eyles JM (1955) James Parkinson; 1755-1824. Nature, 176, 580-581.

[31] Davies G (2007) Whatever is under the earth: The geological society of London 1807 to 2007, Geological Society, London.

[32] Parkinson J (1811) Observations on some of the Strata in the Neighbourhood of London, and on the Fossil remains contained in them. Transactions of the Geological Society of London, 1, 324-354.

[33] Parkinson J (1822) Outlines of oryctology, M.A. Nattali, London.

[34] Sowerby J (1821) The Mineral Conchology of Great Britain; or Coloured Figures and Descriptions of those Remains of Testaceous Animals or Shells, Which Have Been Preserved at Various Times, and Depths in The Earth.

[35] (1823) RCS-GOV-/1/1/3. Minutes of the courst of assistants and council, Royal College of Surgeons, 4, 114-118.

[36] (1824) Obituary notice. Gentlemans magazine, 94, 644

[37] Lawden M (2011) Parkinson's facies. Practical Neurology, 11, 316 . 